J. clin. Path., 1974, 27, 875-879

\title{
Folates in human serum
}

\author{
K. RAtANASThiEN, J. A. Blair, R. J. LEEMING, W. T. COOKE, AND \\ V. MELIKIAN
}

From the University of Aston in Birmingham, the General Hospital, Steelhouse Lane, Birmingham, and Dudley Road Hospital, Birmingham

SYNOPSIS Constituent serum folates have been shown to be altered and in some cases raised in diseases in which total folate levels are known to be frequently decreased. Absorption experiments showed that orally administered folate analogues affect the folate pool in different ways. The stability of the 10 -formyltetrahydrofolate level in normal subjects is demonstrated.

The association of low serum folate levels with adult coeliac disease (Cooke, Fone, Cox, Meynell, and Gaddie, 1963; Dormandy, Waters, and Mollin, 1963) and leukaemia (Rama Rao, Lagerlof, Einhorn, and Reizenstein, 1965) is established although the pathogenesis of the relationship is less well understood. The fate of orally administered pteroyl-Lmonoglutamic acid is well documented (Dormandy et al, 1963; Butterworth, Nadel, Perez-Santiago, Santini, Rafael, and Gardner, 1957; Chanarin, Anderson, and Mollin, 1958; Melikian, Paton, Leeming, and Portman-Graham, 1971; Leeming, Portman-Graham, and Blair, 1972). There is information on the absorption of the folate analogues (Baker, Frank, Feingold, Ziffer, Gellene, Leevy, and Sobotka, 1965; Perry and Chanarin, 1970; Nixon and Bertino, 1972; Brown, Scott, Foster, and Weir, 1973) but less on their impact on the components of the total folate pool.

This study describes relative levels of 5-methyltetrahydrofolic acid (5Me-THF), 10-formyltetrahydrofolic acid (10-CHO-THF), and 10-formylfolic acid (10-CHO-FA) in normal subjects and in patients with adult coeliac disease and leukaemia.

The effects of orally administered folates on individual serum constituents are demonstrated.

\section{Materials and Methods}

Pteroyl-L-monoglutamic acid was a commercial product. The calcium salt of 5-formyltetrahydrofolic acid (5-CHO-THF) was a gift from Lederle Laboratories Ltd; 5-Me-THF-Ca salt was prepared according to Blair and Saunders (1970), 10-CHO-FA according to Blakley (1959), and 5,10-methenylTHF by the method of Roth, Hultqvist, Fahrenbach,

Received for publication 14 August 1974.
Cosulich, Broquist, Brockman, Smith, Parker, Stokstad, and Jukes (1952). All products were checked for purity and identity by (a) microbiological assay with $L$. casei, $S$. faecalis, and $P$. cerevisiae, (b) uv spectra in water at $\mathrm{pH} \mathrm{1,7,} \mathrm{and} \mathrm{13,} \mathrm{and} \mathrm{(c)}$ thin-layer chromatography in three solvent systems, namely, $0 \cdot 1 \mathrm{M}$ phosphate buffer $\mathrm{pH} 7 \cdot 0$, butanol: acetic acid:water $(4: 1: 5 \mathrm{v} / \mathrm{v}$, upper phase), an propanol:1 \% ammonia $(2: 1 \mathrm{v} / \mathrm{v})$.

Five $\mathrm{mg}$ doses of biologically active materials were prepared for absorption experiments. The subjects fasted overnight and during the collection of blood samples. Blood specimens were taken aseptically immediately before the administration of folates and then at 30,60,90,120,180 and, in some instances, at 240,300 , and 360 minutes. They were immediately decanted into glass specimen containers and stood at room temperature for half to one hour. After centrifugation the sera were stored at $-20^{\circ} \mathrm{C}$ with the addition of $5 \mathrm{mg} / \mathrm{ml}$ ascorbic acid and thawed immediately before adding to assay tubes. Assays were carried out as soon as possible after the collection of specimens and always within seven days.

Single samples were taken after a normal lunch.

L. casei assays were carried out using an aseptic technique (Herbert, 1966). Streptococcus faecalis and $P$. cerevisiae assays were also performed aseptically. Bioautography (Leeming, Portman-Graham, Swan, and Blair, 1970) with the three test organisms was used to confirm the identity of the serum folates after absorption.

The normal subjects were hospital staff and medical students.

\section{Results}

The individual serum folates in normal subjects and in the diseased states are given in table I. 


\begin{tabular}{|c|c|c|c|c|c|c|c|c|c|}
\hline \multirow[t]{2}{*}{ Subjects } & \multirow{2}{*}{$\begin{array}{l}\text { No. of } \\
\text { Subjects }\end{array}$} & \multicolumn{2}{|c|}{$5 \mathrm{Me}-T H F\left(\mathrm{ng} / \mathrm{cm}^{2}\right)$} & \multicolumn{2}{|c|}{$10 \mathrm{CHO}-T H F\left(\mathrm{ng} / \mathrm{cm}^{2}\right)$} & \multicolumn{2}{|c|}{$10 \mathrm{CHO}-\mathrm{FA}\left(\mathrm{ng} / \mathrm{cm}^{2}\right)$} & \multicolumn{2}{|c|}{ S. faecalis $\left(\mathrm{ng} / \mathrm{cm}^{2}\right)$} \\
\hline & & Mean $\pm S E M$ & $t$ Test $(\%)$ & $M e a n \pm S E M$ & $t$ Test $(\%)$ & Mean $\pm S E M$ & $t$ Test $(\%)$ & Mean $\pm S E M$ & t Test $(\%)$ \\
\hline \multirow{2}{*}{$\begin{array}{l}\text { Normal } \\
\text { Leukaemia } \\
\text { Adult coeliac } \\
\text { disease }\end{array}$} & $\begin{array}{l}51 \\
41\end{array}$ & $\begin{array}{l}4.80 \pm 0.28 \\
3 \cdot 70 \pm 0.37\end{array}$ & $\overline{<1}$ & $\begin{array}{l}0.57 \pm 0.03 \\
0.50 \pm 0.03\end{array}$ & $\overline{\mathbf{N S}}$ & $\begin{array}{l}0.21 \pm 0.03 \\
0.70 \pm 0.08\end{array}$ & - & $\begin{array}{l}0.78 \pm 0.03 \\
1.23 \pm 0.07\end{array}$ & $\overline{<}_{0.05}$ \\
\hline & 56 & $4.59 \pm 0.46$ & NS & $0.56 \pm 0.03$ & NS & $0.54 \pm 0.07$ & $<0.05$ & $1 \cdot 1 \pm 0.06$ & $<0.05$ \\
\hline
\end{tabular}

Table I Mean levels of folate analogues in normal controls and patients with leukaemia and adult coeliac disease

\begin{tabular}{|c|c|c|c|c|}
\hline Folate Analogues & $R f$ Values & L. casei & S. faecalis & P. cerevisiace \\
\hline $\begin{array}{l}\text { Folic acid } \\
10 \text { CHO-FA } \\
10 \text { CHO-THF } \\
5 \text { CHO-THF } \\
5 \text { Me-THF }\end{array}$ & $\begin{array}{l}0.05 \\
0.60 \\
0.45 \\
0.50 \\
0.65\end{array}$ & $\begin{array}{l}+ \\
+ \\
+ \\
+ \\
+\end{array}$ & $\begin{array}{l}+ \\
+ \\
+ \\
+\end{array}$ & $\begin{array}{l}- \\
\bar{t} \\
\dot{t}\end{array}$ \\
\hline
\end{tabular}

Table II Bioautographic $R f$ values and microbiological activity of folates on cellulose TLC developed in $3 \%$ ammonium chloride

${ }^{1}(t)=$ tail

The Rf values of the folates are given in table II, together with their activity for the three test organisms.

$L$. casei is active for all folates in serum whilst Strep. faecalis is active for all except 5-methyltetrahydrofolic acid (Johns and Bertino, 1965); therefore, the difference in activity of these two test organisms is a measure of 5-methyltetrahydrofolic acid. $P$. cerevisiae is active for 10 formyl-tetrahydrofolic acid 5-formyltetrahydrofolic acid but not for 10-formylfolic acid or folic acid whereas Streptococcus faecalis is active for all four compounds. Therefore the difference between the $S$. faecalis and $P$. cerevisiae assays measures the amount of folic acid and 10-formylfolic acid present.

Bioautography of serum and urine samples showed that except after folic acid administration the folate responsible for the $S$. faecalis- $P$. cerevisiae difference is 10-formylfolic acid. Of the folates active for $P$. cerevisiae, only 10-CHOTHF is found in serum (Nixon and Bertino, 1972). Individual folates were further identified by bioautography in $3 \%$ aqueous ammonium chloride, a solvent system in which all commonly occurring folate monoglutamates are clearly separated (Leeming et al, 1970; Brown, Davidson, and Scott, 1973). Additional precision in identification was obtained by carrying out bioautography with $L$. casei, $S$. faecalis, and $P$. cerevisiae as developing microorganisms.

The correlation of total folate and 5-Me-THF is shown in figs 1 and figs 2-6 show serum folate constituents after oral administration of folate analogues. In 10 patients with adult coeliac disease on long-term treatment with folic acid, the mean values of the total folate, Streptococcus faecalis, and $P$. cerevisiae (10-CHOTHF) levels were $>20.0,>3.0$, and $0.56 \mathrm{ng} / \mathrm{cm}^{3}$ respectively.

\section{Discussion}

Three folates can be assayed in normal human blood serum. The means of our values were 5-methyltetrahydrofolic acid, $4.80 \mathrm{ng} / \mathrm{cm}^{3}, 10$-formyltetrahydrofolic acid, $0.57 \mathrm{ng} / \mathrm{cm}^{3}$, and 10-formylfolic acid 0.21 $\mathrm{ng} / \mathrm{cm}^{3}$ (table I). As 10-formyltetrahydrofolic acido is very readily oxidized to 10 -formylfolic acid (similar

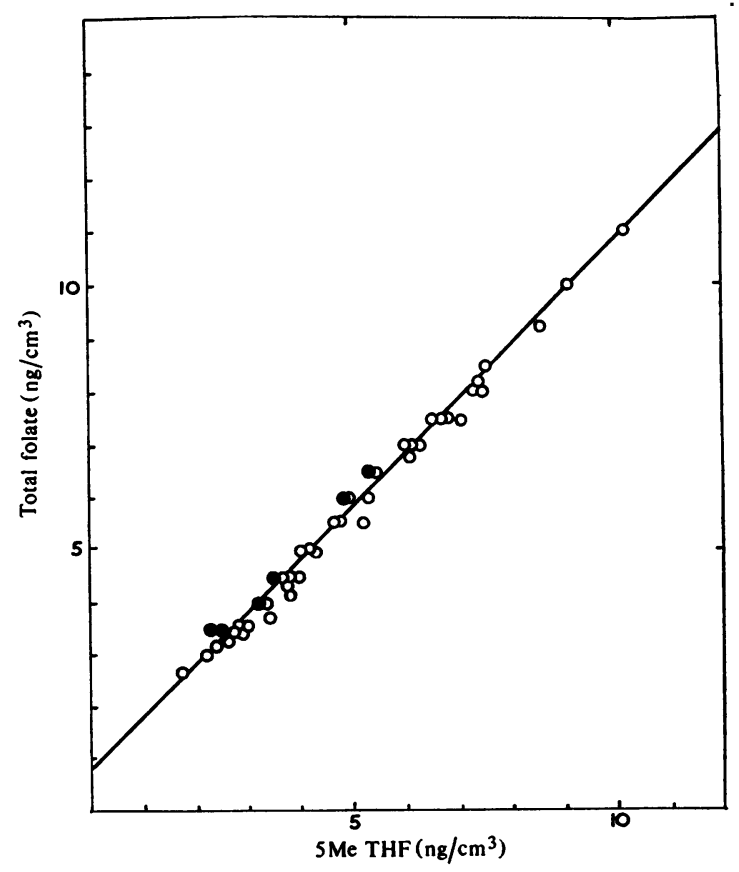

Fig 1 Correlation of total folate and 5-methyltetrahydrofolate levels in 51 normal subjects. 
Symbols for figs 2-6 together with standard errors of means.
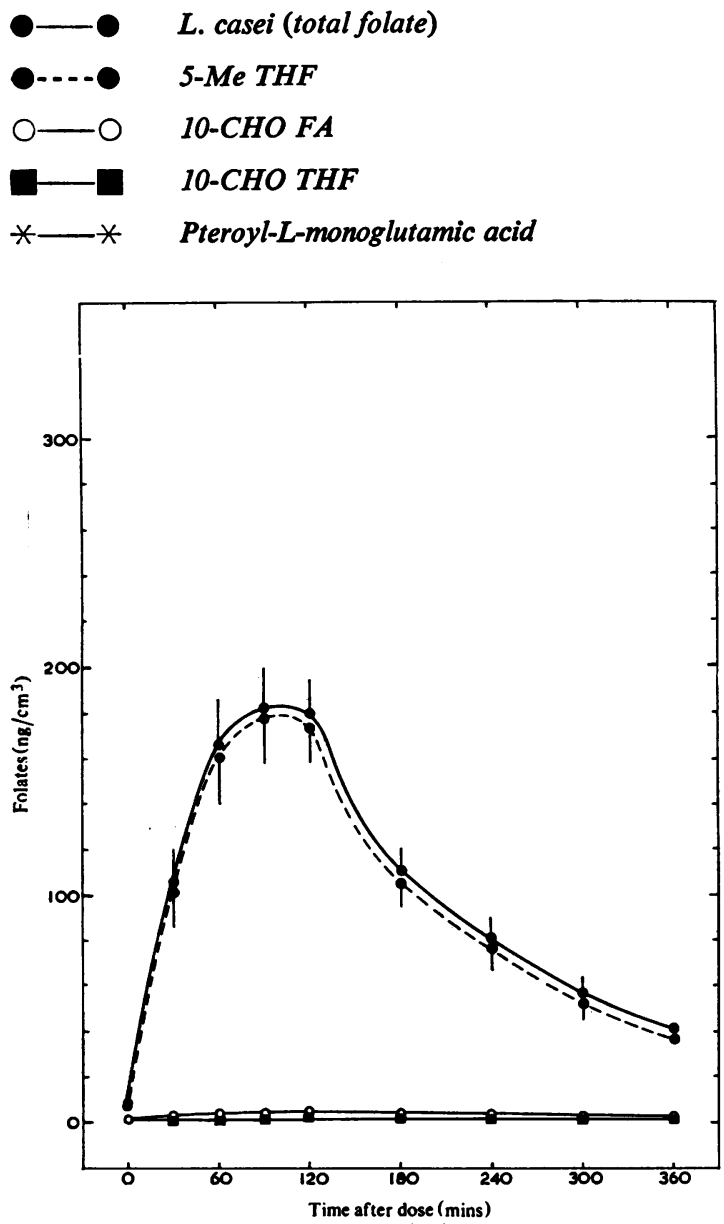

Fig 2 The effect of orally administered 5-Me-THF $(10 \mathrm{mg})$ on the mean levels of folate analogues in six subjects.

to tetrahydrofolic acid (Blair and Pearson, 1974), the 10-formylfolic acid is very likely an analytical artifact. When serum samples were taken and analysed under carefully controlled conditions no 10-formylfolic acid could be identified. The 10-formyltetrahydrofolic acid level in serum is thus best represented by the $S$. faecalis level. Normal serum folates are therefore 5-methyltetrahydrofolic acid $4.80 \mathrm{ng} / \mathrm{cm}^{3}$ and 10-formyltetrahydrofolic acid $0.78 \mathrm{ng} / \mathrm{cm}^{3}$.

In man 5-formyl and 5-methyltetrahydrofolic acid and folic acid are converted into 10-formyltetrahydrofolic acid (Albrecht and Broquist, 1956; Silverman, Ebaugh, and Gardiner, 1956; Nixon and Bertino, 1972) and 10-formyltetrahydrofolic acid adminis-

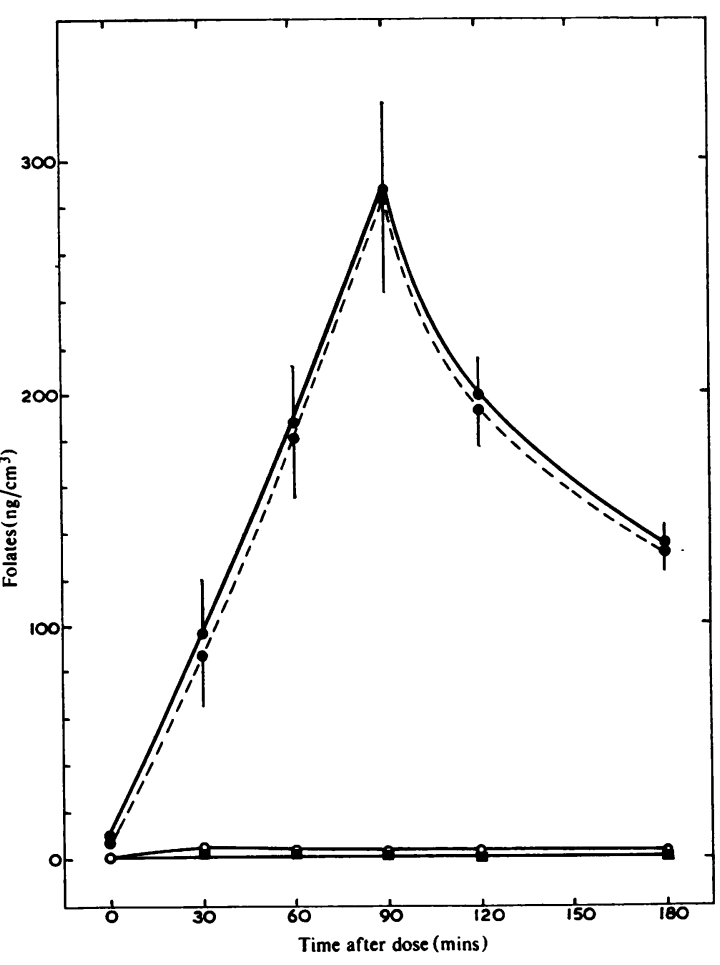

Fig 3 The effect of orally administered 5-CHO THF $(10 \mathrm{mg})$ on the mean levels of folate analogues in six subjects.

tered as 5,10 -methenyltetrahydrofolic acid is converted into 5-methyltetrahydrofolic acid (fig 4). Thus the two serum folates are in dynamic metabolic equilibrium.

When the total serum folates are plotted against the serum 5-methyltetrahydrofolic acid, an excellent straight line fit with an intercept on the total folate axis at $0.8 \mathrm{ng} / \mathrm{cm}^{3}$ is obtained (fig 1). Therefore, normal serum folates consist of a constant level of 10-formyltetrahydrofolic acid maintained by some homeostatic mechanism and a variable level of 5-methyltetrahydrofolic acid acting as storage form. Statistical analysis of the $S$. faecalis and $P$. cerevisiae values show them to be normally distributed about the mean as might be expected for the analysis of a serum component maintained at a constant level. Similar analysis of the $L$. casei values show them to have a skewed distribution about the mean as might be expected from a summation of serum components, one of which varies with dietary intake.

Further confirmation of the homeostatic control of 10-formyltetrahydrofolic acid levels and the role of 5-methyltetrahydrofolic acid as a storage form is shown by the changes in serum folates after oral 


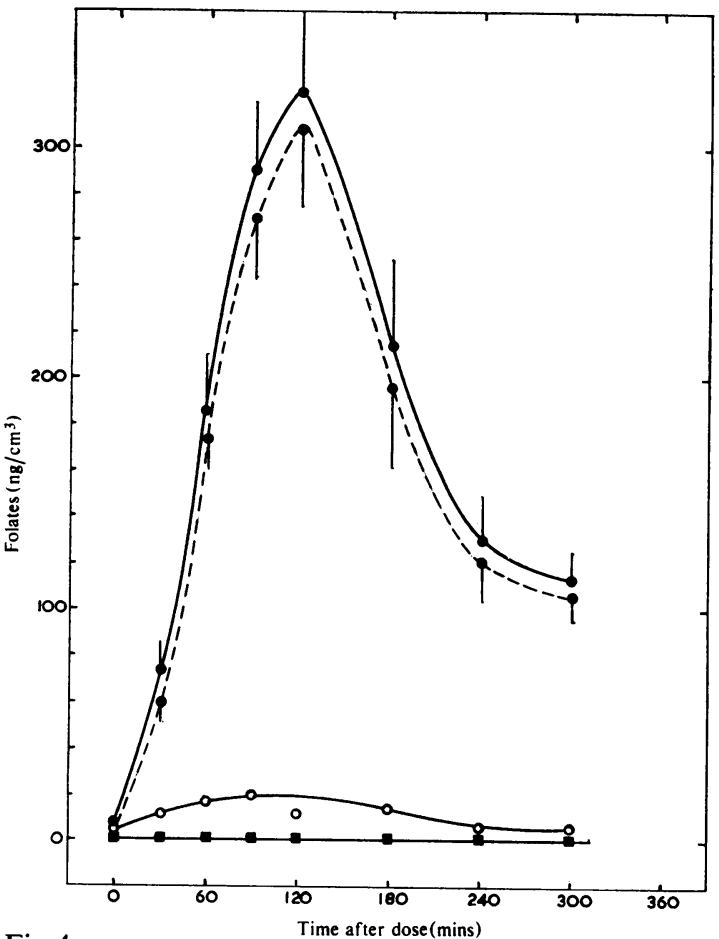

Fig 4

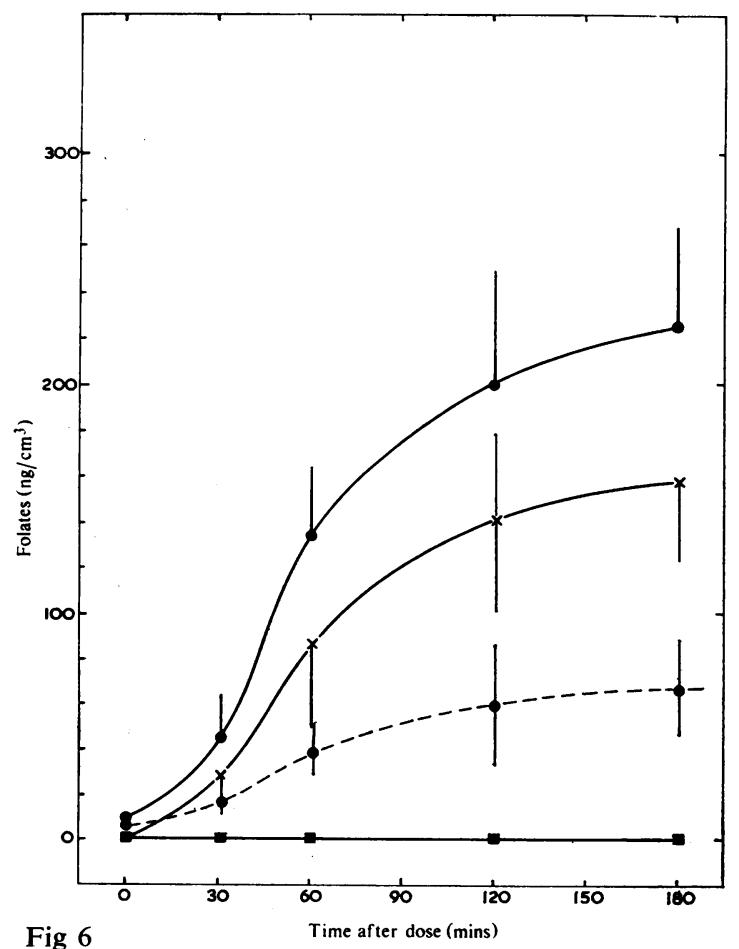

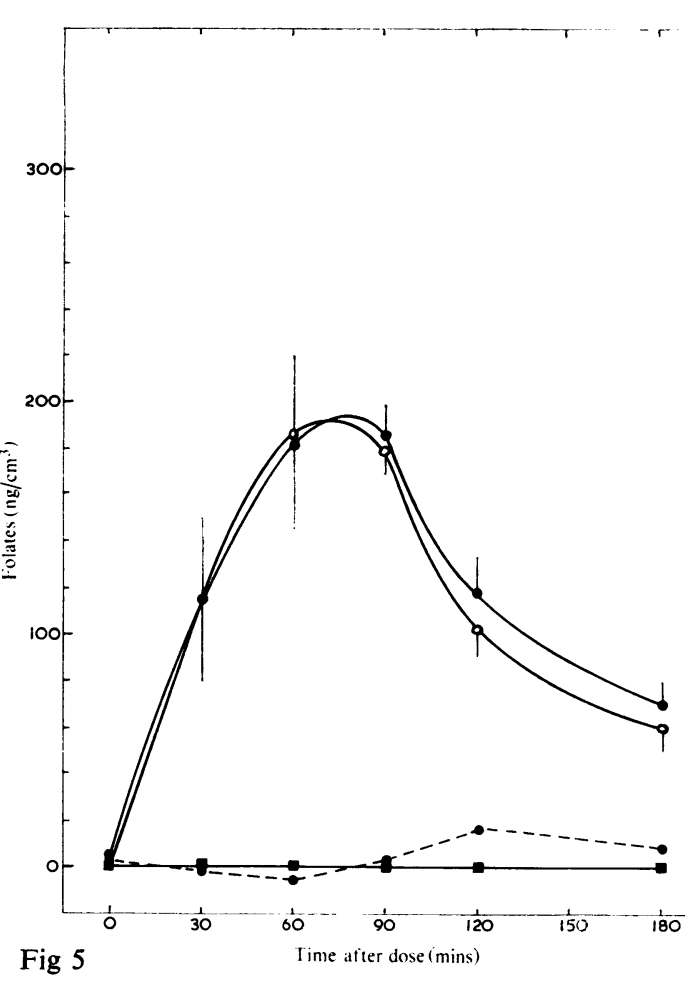

Fig 4 The effect of orally administered 5,10 methenyl THF (10 mg) on the mean levels of folate analogues in six subjects.

Fig 5 The effect of orally administered 10-CHO FA $(5 \mathrm{mg})$ on the mean levels of folate analogues in six subjects.

Fig 6 The effect of orally administered pteroyl-Lmonoglutamic acid $(5 \mathrm{mg})$ on the mean levels of folate analogues in six subjects.

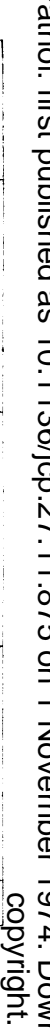

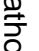

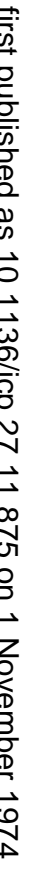


doses of folates. After oral doses of folic acid, 10formylfolic acid, 5-formyltetrahydrofolic acid, 5,10methenyltetrahydrofolic acid, and 5-methyltetrahydrofolic acid total serum folates rise rapidly to high levels while the 10-formyltetrahydrofolic acid remains practically constant (figures 2-6). Long-term administration of folic acid also fails to raise the 10-formyltetrahydrofolic acid level. The 10-formylfolic acid is not converted to 5-methyltetrahydrofolic acid (figure 5). As previously noted (Leeming et al, 1972), folic acid is slowly converted to 5-methyltetrahydrofolic acid (figure 6). The 5,10-methenyltetrahydrofolic acid also gives a small amount of serum 10 -formylfolic acid probably derived by oxidation of 10-formyltetrahydrofolic acid in the jejunum before absorption (figure 4) (Beavon and Blair, 1972; Blair and Pearson, 1974). The persistence of these small amounts of 10-formylfolic acid in the serum again shows that this compound is not converted to 5-methyltetrahydrofolic acid.

The relative peak serum levels obtained after administration of folic acid and the tetrahydrofolates, particularly the high level after 5,10-methenyl-THF, was similar to that shown by Brown et al (1973) although these authors did not use differential microbiological assays or separative techniques to identify individual serum constituents.

Measurement of the individual serum folates in adult coeliac disease and leukaemia shows a significant increase over normals of the 10-formylfolic acid level (table I). However, if as in normal subjects this is an analytical artefact derived from the oxidation of 10-formyltetrahydrofolic acid then in both adult coeliac disease and leukaemia there are significantly increased levels of serum 10-formyltetrahydrofolic acid. In the leukaemic subjects both total folate and 5-methyltetrahydrofolic acid are significantly reduced (table I).

Sotobayashi, Rosen, and Nichol (1965) showed that tissues with high cell replication rates had a much smaller pioportion of folate as 5-methyltetrahydrofolic acid and a much higher proportion as 10formyltetrahydrofolic acid (or derived compounds) than tissues with slow cell replication rates. Thus the increased serum levels of 10-formyltetrahydrofolic acid in adult coeliac disease and leukaemia may be due to the increased cell replication rate in these diseases.

We are grateful to Dr Michael L. Lucas for carrying out the statistical analyses.
References

Albrecht, A. M., and Broquist, H. P. (1956). Evidence for occurrence of 10-formyltetrahydrofolic acid in human urine, Proc. Soc. exp. Biol. (N.Y.), 92, 158-163.

Baker, H., Frank, O., Feingold S., Ziffer, H., Gellene, R. A., Leevy, C. M., and Sobotka, H. (1965). The fate of orally and parenterally administered folates. Amer. J. clin. Nutr., 17, 88-95.

Beavon, J. R. G., and Blair, J. A. (1972). The pH dependent rearrangements of formyltetrahydrofolates and their nutritional implications, Brit. J. Nutr., 28, 385-390.

Blair, J. A., and Pearson, A. J. (1974). Kinetics and mechanism of the autooxidation of the 2-amino-4-hydroxy-5,6,7,8-tetrahydropteridines. J. chem Soc. (Perkin II Transactions), 8088.

Blair, J. A., and Saunders, K. J. (1970). A convenient method for the preparation of dl-5-methyltetrahydrofolic acid (dl-5-methyl5,6,7,8-tetrahydropteroyl-L-monoglutamic acid. Analyt. Biochem., 34, 376-381.

Blakley, R. L. (1959). The reaction of tetrahydropteroyl glutamic acid and related hydropteridines with formaldehyde. Biochem. J., 72, 707-715.

Brown, J. P., Davidson, G. E., and Scott, J. M. (1973). Thin-layer chromatography of pteroylglutamates and related compounds. J. Chomatogr., 79, 195-207.

Brown, J. P., Scott, J. M., Foster, F. G. and Weir, D. G. (1973). Ingestion and absorption of naturally occurring pteroylmonoglutamates (folates) in man. Gastroenterology, 64, 223-232.

Butterworth, C. E., Jr., Nadel, H., Perez-Santiago, E., Santini, R., Jr., and Gardner, F. H. (1957). Folic acid absorption excretion, and leukocyte concentration in tropical sprue. J. Lab. clin. Med., 50, 673.681.

Chanarin, I., Anderson, B. B., and Mollin, D. L. (1958). The absorption of folic acid. Brit. J. Haemat., 4, 156-166.

Cooke, W. T., Fone, D. J., Cox, E. V., Meynell, M. J., and Gaddie, R. (1963). Adult coeliac disease. Gut, 4, 279-291.

Dormandy, K. M., Waters, A. H., and Mollin, D. L. (1963). Folic acid deficiency in coeliac disease. Lancet, 1, 632-635.

Herbert, V. (1966). Aseptic addition method for L. casei assay of folate activity in human serum. J. clin. Path., 19, 12-16.

Johns, G., and Bertino, J. R. (1965). Folates and megaloblastic anaemia: a review. Clin. pharm. Ther., 6, 372-392.

Leeming, R. J., Portman-Graham, H., and Blair, J. A. (1972). The occurrence of folic acid (pteroyl-L-monoglutamic acid) in human blood serum after small oral doses. J. clin. Path., 25, 491-493.

Leeming, R. J., Portman-Graham, H., Swan, C. H. J., and Blair, J. A. (1970). The application of tetrazolium bioautography to the identification of folic acid derivatives. J. clin. Path., 23, 411-413.

Melikian, V., Paton, A., Leeming, R. J., and Portman-Graham, H. (1971). Site of reduction and methylation of folic acid in man. Lancet, 2, 955-957.

Nixon, P. F., and Bertino, J. R. (1972). Effective absorption and utilization of oral formyltetrahydrofolate in man. New Engl. J. Med., 286, 175-179.

Perry, J., and Chanarin, I. (1970). Intestinal absorption of reduced folate compounds in man. Brit. J. Haemat., 18, 329-339.

Rama Rao, P. B., Lagerlöf, B., Einhorn, J., and Reizenstein, P. G. (1965). Folic acid activity in leukemia and cancer. Cancer Res., 25, 221-224.

Roth, B., Hultqvist, M. E., Fahrenbach, M. J., Cosulich, D. B., Broquist, H. P., Brockman, J. A., Jr., Smith J. M., Jr., Parker, R. P., Stokstad, E. L. R., and Jukes, T. H. (1952). Synthesis of leucovorin. J. Amer. chem. Soc., 74, 3247-3263.

Silverman, M., Ebaugh, F. G., Jr., and Gardiner, R. C. (1956). The nature of labile citrovorum factor in human urine. J. biol. Chem., 223, 259-270.

Sotobayashi, H., Rosen, F., and Nichol, C. A. (1966). Tetrahydrofolate cofactors in tissues sensitive and refractory to amethopterin. Biochemistry, 5, 3878-3883. 